\title{
NÍVEIS DE VITAMINA D E SUA SUPLEMENTAÇÃO EM RELAÇÃO AO RISCO DE MORTE POR CAUSA ESPECÍFICA: DISCUSSÃO E RESUMO DE UMA METANALISE RECENTEMENTE PUBLICADA
}

Felipe Dunin dos Santos; Cristina Pelegrino Baena²; Carolina Aguiar Moreira Kulak1; Eliane Carmes ${ }^{1}$; Francisco Magalhães'; Gibran Avelino Frandoloso'; Maria Aparecida Pachaly'; Mauricio de Carvalho', ${ }^{2}$

\section{RESUMO}

Existem duas formas de vitamina D: vitamina D2 (ergocalciferol) e vitamina D3 (colecalciferol). A suplementação de vitamina D melhora condições ósseas como raquitismo, diminui a incidência de fraturas e quedas. Postula-se que essa reposição de vitamina $D$ poderia também reduzir os riscos de desenvolvimento de várias doenças, como esclerose múltipla, doenças autoimunes e infecções. Apesar do grande número de estudos, os benefícios do uso da vitamina D na população em geral permanecem controversos. Propõese a discussão de um artigo de revisão e metanálise que contempla a relação dos níveis séricos de vitamina $D$ e sua suplementação com associação de risco de morte

Palavras-Chave: Vitamina D; Deficiência de Vitamina D; Mortalidade

\footnotetext{
1- Universidade Federal do Paraná

2- Pontifícia Universidade Católica do Paraná
}

Contato do Autor/ Mail to:

Felipe Dunin dos Santos - dcm@ufpr.br

Rua General Carneiro, 181- Alto da Glória - Curitiba - PR - 80060-900, 10andar, Departamento de Clínica Médica 


\section{RESUMO E DISCUSSÃO}

Existem duas formas de vitamina D: vitamina D2 (ergocalciferol), produzida pelas plantas, através da irradiação do ergosterol e vitamina D3 (colecalciferol), obtida pela irradiação do 7-dehidrocolesterol na epiderme humana ou obtida pelo consumo externo. A suplementação de vitamina $D$ melhora condições ósseas como raquitismo, fraturas e quedas. E poderia reduzir riscos de várias doenças, como esclerose múltipla, doenças autoimunes, infecções e outras. Apesar do número grande de estudos, os benefícios da suplementação de vitamina $D$ na população em geral permanecem controversos. Recentemente foi realizada uma revisão sistemática e meta-análise, onde os investigadores determinaram se os níveis séricos de vitamina $D$ e a sua suplementação foram associados com risco de morte.

A meta-análise foi realizada de acordo com um protocolo e com as diretrizes PRISMA e MOOSE. Foram analisados estudos publicados até 1 o de agosto de 2013, com emprego das bases de dados Medline, Embase e Cochrane, aplicando termos relacionados com a exposição e com os resultados da suplementação. Os estudos deveriam relacionar a associação da vitamina $D$ circulante ou a suplementação de vitamina D com mortalidade.

Foram selecionados 73 estudos observacionais, com seguimento médio de 0,3 a 29 anos. Estes estudos acompanharam 850 mil participantes, com média de idade de 63 anos (59-71) e níveis séricos de 25-OHvitamina $D$ de $20,7 \mathrm{ng} / \mathrm{mL}$. Quando se comparou os participantes cujos níveis de
25-OH-vitamina D estavam no terço superior com aqueles cujos níveis estavam no terço inferior, detectou-se maior risco para doenças cardiovasculares (RRA, risco relativo ajustado, 1,4), para mortes relacionadas a câncer (RRA, 1,1), e para mortalidade geral (RRA, 1,4) no grupo com níveis menores de vitamina D. Para cada diminuição de $10 \mathrm{ng} / \mathrm{mL}$ de vitamina $D$ no sangue, o risco mortalidade geral aumentou 16\%, Figura 1.

A outra parte dessa meta-análise compreendeu 22 ensaios randomizados e controlados com placebo. Foram estudados 31.000 indivíduos, com média de idade de 77 anos (56-85) e seguimento de 0,4 a 6,8 anos. Em oito estudos foi utilizada a vitamina D2 (intervalo de doses, 208-4500 UI/dia) e em 14 foi estudada a vitamina D3 (intervalo de doses, 10-6000 IU/dia). A suplementação de vitamina D3, porém não a suplementação com vitamina D2, reduziu significativamente o risco de mortalidade geral (risco relativo de 0,9), Figura 2.

Os dados observacionais mostraram uma associação inversa entre os níveis sanguíneos de $25-\mathrm{OH}$ vitamina $D$ e mortalidade, mas causalidade reversa é possível (ou seja, doentes com níveis baixos de vitamina D por causa da doença ao invés de níveis baixos de vitamina $D$ causando doença). Apesar da maioria dos estudos randomizados incluídos neste estudo ter baixo risco de viés, os achados devem ser interpretados com cuidado, devido ao número pequeno de trials para cada subtipo de intervenção. 


\section{REVISTA MÉDICA DA UFPR}

\begin{tabular}{|c|c|c|c|c|c|}
\hline & $\begin{array}{l}\text { No of } \\
\text { studies }\end{array}$ & $\begin{array}{c}\text { No of } \\
\text { participants }\end{array}$ & $\begin{array}{l}\text { No of } \\
\text { deaths }\end{array}$ & $\begin{array}{l}\text { Relative risk }(95 \% \mathrm{Cl})^{*} \text { for } \\
\text { cause specific mortality }\end{array}$ & $\begin{array}{l}\text { Relative risk }(95 \% \mathrm{Cl}) * \mathrm{f} \\
\text { cause specific mortality }\end{array}$ \\
\hline \multicolumn{6}{|l|}{ Cardiovascular death } \\
\hline Primary prevention cohorts & 19 & 80662 & 6416 & $\longrightarrow$ & $1.35(1.13$ to 1.61$)$ \\
\hline Secondary prevention cohorts & 10 & 20987 & 3787 & $\longrightarrow$ & $1.60(1.32$ to 1.94$)$ \\
\hline All cohorts & 29 & 101649 & 10203 & $\longrightarrow-$ & $1.43(1.25$ to 1.64$)$ \\
\hline \multicolumn{6}{|l|}{ Cancer death } \\
\hline Primary prevention cohorts & 12 & 104353 & 5003 & $\rightleftarrows-$ & $1.14(1.01$ to 1.29$)$ \\
\hline Secondary prevention cohorts & 5 & 16382 & 1617 & — & $1.59(1.17$ to 2.16$)$ \\
\hline All cohorts & 17 & 120735 & 6620 & $\rightarrow-$ & $1.25(1.10$ to 1.43$)$ \\
\hline \multicolumn{6}{|c|}{ Non-cardiovascular, non-cancer death } \\
\hline Primary prevention cohorts & 7 & 38526 & 1444 & $\longrightarrow$ & $1.30(1.07$ to 1.59$)$ \\
\hline Secondary prevention cohorts & 3 & 13035 & 1121 & $\longrightarrow-$ & $1.49(0.94$ to 2.35$)$ \\
\hline All cohorts & 10 & 51561 & 2565 & $\longrightarrow$ & $1.34(1.13$ to 1.60$)$ \\
\hline \multicolumn{6}{|l|}{ All cause mortality } \\
\hline Primary prevention cohorts & 27 & 780990 & 48488 & $\rightarrow-$ & $1.35(1.22$ to 1.49$)$ \\
\hline Secondary prevention cohorts & 41 & 59918 & 16148 & $\rightarrow-$ & $1.50(1.36$ to 1.65$)$ \\
\hline \multirow[t]{2}{*}{ All cohorts } & 68 & 840908 & 64636 & - & $1.44(1.34$ to 1.55$)$ \\
\hline & & & 0.5 & 1 & 2.5 \\
\hline
\end{tabular}

Fig 1 Association of circulating 25-hydroxyvitamin D concentrations with cause specific mortality in observational cohort studies. *Pooled estimates are based on random effects meta-analysis. Using fixed effects models, for primary prevention cohorts, secondary prevention cohorts, and all cohorts, the estimates were 1.40 (1.32 to 1.47 ), 1.50 (1.35 to 1.66), and 1.42 (1.35 to 1.49 ) for cardiovascular deaths; 1.10 (1.02 to 1.17), 1.45 (1.28 to 1.65 ), and 1.16 (1.10 to 1.24 ) for cancer deaths; 1.28 (1.12 to 1.47$), 1.38$ (1.09 to 1.75$)$, and 1.30 (1.16 to 1.47 ) for non-vascular, non-cancer deaths; and 1.45 (1.41 to 1.49$), 1.49$ (1.42 to 1.56 ), and 1.44 (1.40 to 1.47) for all cause deaths. Size of data marker is proportional to inverse of variance of relative risk; horizontal line represents $95 \% \mathrm{Cl}$. Corresponding forest plots and $\mathrm{I}^{2}(95 \% \mathrm{Cl})$ estimates are provided in supplementary material

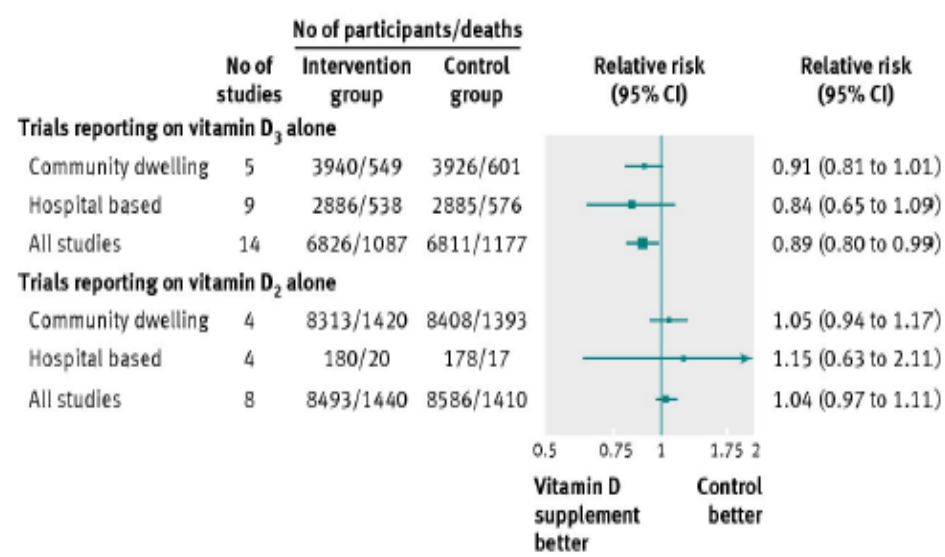

Fig 6 Effects of vitamin D supplementation on all cause mortality when given alone, derived from available randomised control trials. *Pooled estimates are based on random effects meta-analysis. Using fixed effects models, for community dwelling, hospital based, and overall population, the estimates were 0.91 ( 0.81 to 1.01$), 0.88$ ( 0.77 to 1.01$)$, and 0.90 ( 0.82 to 0.98 ) for vitamin $D_{3}$ trials and 1.05 (0.94 to 1.17$), 1.15(0.63$ to 2.11$)$, and $1.03(0.97$ to 1.09$)$ for vitamin $D_{2}$ trials. Overall fixed effect estimate for all trials was 0.98 ( 0.94 to 1.03). Size of data marker is proportional to inverse of variance of relative risk; horizontal line represents $95 \% \mathrm{Cl}$. Corresponding forest plots and $\mathrm{I}^{2}(95 \% \mathrm{Cl})$ estimates are provided in supplementary material

\section{REFERÊNCIAS}

1. Chowdhury $R$ et al. Vitamin D and risk of cause specific death: Systematic review and meta-analysis of observational cohort and randomised intervention studies BMJ 2014 Apr 1; 348:g1903. Disponível em: (http://dx.doi.org/10.1136/bmj.g1903) 